\title{
UPAYA MENINGKATKAN HASIL BELAJAR IPS MELALUI MODEL PEMBELAJARAN KOOPERATIF TIPE JIGSAW BAGI PESERTA DIDIK KELAS IV SDN-2 KASONGAN BARU TAHUN PELAJARAN 2016/2017
}

\section{Oleh : ELDA*Suniati, M.Pd}

\begin{abstract}
ABSTRAK
Penelitian ini bertujuan untuk : (1) Untuk mengetahui aktivitas peserta didik pada pelajaran IPS dengan menggunakan model pembelajaran Kooperatif Tipe Jigsaw,(2) Untuk mengetahui peningkatan hasil belajar IPS dengan model pembelajaran Kooperatif Tipe Jigsaw pada peserta didik di Kelas IV SDN -2 Kasongan Baru Kecamatan Katingan Hilir Kabupaten Katingan. Jenis penelitian ini adalah menggunakan rancangan penelitian tindakan kelas (PTK) yang berusaha memecahkan atau menjawab permasalahan yang dihadapi pada situasi sekarang dengan subjek penelitian seluruh peserta didik di kelas IV SDN - 2 Kasongan Baru yang berjumlah 12 orang, teknik pengumpulan data yang digunakan adalah observasi dan tes. Teknik analisis data menggunakan teknik kualitatif dan kuantitatif.
\end{abstract}

Kata Kunci : Hasil belajar IPS, dan model pembelajaran kooperatif tipe Jigsaw.

\section{PENDAHULUAN}

Pendidikan merupakan salah satu upaya untuk membangun dan meningkatkan mutu sumber daya manusia menuju era globalisasi yang penuh dengan tantangan, sehingga disadari bahwa pendidikan merupakan salah satu hal yang sangat penting bagi setiap individu. Oleh karena itu pendidikan tidak bisa diabaikan begitu saja. Dalam keseluruhan upaya pendidikan, proses belajar mengajar merupakan aktivitas yang paling penting, karena melalui itulah tujuan pendidikan akan dicapai dalam bentuk perubahan perilaku siswa.Undang-Undang sistem pendidikan nasional no. 20 pasal 3 tahun 2003, menyatakan bahwa : Pendidikan Nasioanal bertujuan untuk berkembangnya potensi pesertadidik agar menjadi manusia yang beriman, bertaqwa, kepada Tuhan YangMaha Esa, berakhlak mulia, sehat,cakap, kreatif, madiri dan menjadi warga negara yang demokratis dan bertanggung jawab. 
Guru merupakan ujung tombak perubahan suatu negeri menjadi objek utama yang perlu ditingkatkan profesionalismenya, agar kualitas pembelajaran meningkat. Hal ini dikarenakan kemampuan profesional guru telah resmi dicanangkan oleh pemerintah, bahwa profesi guru disejajarkan dengan profesi lainnya sebagai tenaga profesional.Secara formal, Undang - Undang Republik Indonesia, no. 20 tahun 2003 tentang sistem pendidikan nasional, dan Undang - Undang Republik Indonesia, no. 14 tahun 2005 tentang guru dan dosen, serta peraturan pemerintah no. 19 tahun 2005 tentang standar pendidikan nasional menyatakan bahwa guru adalah tenaga.

Guru adalah pelaku pembelajaran, sehingga dalam hal ini guru merupakan faktor yang terpenting, Ditangan gurulah sebenarnya letak keberhasilan suatu pembelajaran. Komponen guru tidak dapat dimanipulasi atau direkayasa oleh komponen lain, dan sebaliknya guru mampu memanipulasi atau merekayasa komponen lain menjadi bervariasi. Sedangkan peserta didik merupakan komponen yang melakukan kegiatan belajar untuk mengembangkan potensi kemampuan menjadi nyata dalam mencapai tujuan belajar. Komponen peserta didik inilah yang dapat dimodifikasi oleh guru. Sejatinya yang menjadi dasar penyebab suatu perubahan adalah faktor kualitas seseorang untuk selalu ingin berkarya dan berprestasi sepanjanng usia hidupnya, sehingga kebutuhan untuk berkarya bagaikan darah yang mengalir dalam tubuh. Dengan begitu kebutuhan negeri ini untuk mencapai tujuan perubahan yang lebih baikakan tercapai. Didalam proses menyampaikan bahan pembelajaran seorang guru dapat menggunakan metode, model dan media ataupun alat bantu belajar lainnya, agar proses belajar mengajar menjadi lebih mudah untuk dipahami oleh peserta didik. Penggunaan model pembelajaran sangat diperlukan dalam meningkatkan mutu pendidikan khususnya dalam proses belajar mengajar yang sedang berlangsung sehingga dapat berjalan dengan efektif dan efisien.Menurut Supriyono, (Subur, 2015: 23). Model pembelajaran ialah pola yang dipergunakan sebagai pedoman dalam perencanaan pembelajaran di kelas dan biasanya menggambarkan langkah - langkah atau prosedur yang di tempuh guru untuk menciptakan aktivitas pembelajaran yang efektif, efisisen, dan menarik. 
Senada dengan pendapat Supriyono, Kemp (Rusman, 2014 : 132) menyebutkan bahwa model pembelajaran adalah suatu kegiatan yang harus dikerjakan guru dan siswa agar tujuan pembelajaran dapat di capai secara efektif dan efisien.

Dengan keterampilan dan kekreatifan yang dimiliki oleh seorang guru dalam mengolah pembelajaran dengan menggunakan metode, ataupun model pembelajaran, tentu hal tersebut dasar sampai pada kelanjutan yang lebih tinggi. Rendahnya hasil belajar IPS seringkali disebabkan oleh beberapa faktor ataupun permasalahan yang mempengaruhi selama proses pembelajaran berlangsung. Kurangnya pemanfaatan sumber belajar sehingga penanaman konsep IPS masih rendah dan peserta didik hanya berimajinasi tanpa adanya praktek yang nyata. Selain beberapa faktor yang menyebabkan kurangnya hasil belajar IPS pada peserta didik kelas IV di SDN-2 Kasongan Baru, berdasarkan hasil observasi yang saya lakukan, ada pula beberapa kendala ataupun masalah yang ada saat proses pembelajaran IPS berlangsung, pada peserta didik kelas

\section{METODOLOGI PENELITIAN}

\section{Waktu dan Tempat Penelitian}

1. Waktu Penelitian dapat memberikan peluang yang lebih besar dalam meningkatkan hasil belajar peserta didik.Khususnya pada mata pelajaran IPS (Ilmu Pengetahuan Sosial).Dimana mata pelajaran IPS merupakan salah satu pengetahuan dasar yang penting dalam menunjang ilmu pengetahuan dan teknologi. Oleh karena itu pelajaran IPS diberikan secara berkesinambungan pada setiap jenjang pendidikan formal dari sekolah

IV di SDN-2 Kasongan Baru, Kecematan katingan Hilir, Kabupaten Katingan, diantaranya yaitu :

1. Metode yang digunakan kurang bervariasi.

2. Antusias peserta didik dalam belajar IPS masih rendah.Metode ataupun model pembelajaran yang digunakan selama proses pembelajaran berlangsung masih belum efektif. Peserta didik merasa bosan dan kurang bersemangat pada saat proses pembelajaran. Kurangnya pemahaman peserta didik terhadap materi IPS yang dipelajari.

3. Hasil belajar peserta didik masih rendah dibawah ( $\mathrm{KKM})$

Dengan beberapa pertimbangan dan alasan peneliti menentukan menggunakan waktu penelitian selama lima bulan yakni dari bulan Januari 
sampai dengan Mei tahun pelajaran 2017.

2. Tempat Penelitian

Tempat penelitian ini, mengambil lokasi di SDN-2 Kasongan Baru Kecematan Jenis Penelitian :Penelitian ini dilaksanakan dengan menggunakan metode Penelitian Tindakan Kelas (Classroom action research). Menurut Kunandar (2011:42) "Penelitian Tindakan Kelas merupakan bagian dari penelitian tindakan (action research), dan penelitian tindakan ini bagian dari penelitian pada umumnya".Sedangkan menurut Arikunto (2012:58) "Penelitian Tindakan Kelas adalah penelitian tindakan (action research) yang dilakukan dengan tujuan memperbaiki mutu praktik pembelajaran di kelasnya".Penelitian Tindakan Kelas ini berfokus pada upaya untuk mengubah kondisi sekarang ke arah kondisi yang diharapkan yaitu menjadi lebih baik.Secara ringkas, Penelitian Tindakan Kelas adalah bagaimana sekolompok guru dapat mengorganisasikan kondisi praktek pembelajaran mereka, dan belajar dari pengalaman mereka sendiri.Mereka dapat mencobakan suatu gagasan perbaikan dalam praktek pembelajaran mereka, dan melihat pengaruh nyata dari upaya itu.Selain itu, Penelitian Tindakan Kelas juga penelitian yang refleksi yang dilaksanakan secara siklis (berdaur) dimulai dari tahapan
Katingan Hilir, Kabupaten Katingan, Provinsi Kalimantan Tengah.Yang berada dijalan, Pusara Cinta no. 29. Adapun alasan Saya mengambil tempat

perencanaan, tindakan, pengamatan, dan refleksi untuk memecahkan masalah dan mencoba hal-hal baru demi peningkatan kualitas pembelajaran. Dalam hal ini peneliti menggunakan model pembelajaran jigsaw pada mata pelajaran IPS kelas IV di SDN-2 Kasongan Baru, Kecematan Katingan Hilir Kabupaten Katingan adapun hal yang menjadi dasar penelitian ini yaitu hasil belajar peserta didik

\section{Rancangan Penelitian}

Rancangan penelitian adalah keseluruhan proses dan penelitian tentang hal-hal yang berkaitan dengan objek yang akan diteliti dalam mendapatkan hasil yang diinginkan. Penelitian ini dilaksanakan menggunakan pendekatan penelitian tindakan kelas (PTK) yang dipilih dengan tujuan untuk menyelidiki nilai IPS yang kurang. Rancangan PTK dalam penelitian ini adalah rangkaian kegiatan yang berurutan dan berkesinambungan yang dicirikan dengan adanya model kerja yang dilakukan peneliti dengan menggunakan siklus-siklus, setiap siklus terdiri dariempat tahapan yaitu: perencanaan tindakan, pelaksanaan tindakan, observasi, dan 
reflleksi/evaluasi. Sebagaimana tergambar pada bagan berikut in

\section{DESKRIPSI PENELITIAN DAN PEMBAHASAN}

Nilai hasil belajar peserta didik yang dimaksud yaitu peningkatan nilai hasil peserta didik kelas IVSDN-2 Kasongan Baru pada pelajaran IPS dengan standar kompetensi yaitu : 3.Mengenal sumber daya alam, kegiatan ekonomi, dan kemajuan teknologi dilingkungan kabupaten kota dan provinsi.dan kompetensi dasarnya yaitu: 3.1 Mengenal aktivitas ekonomi yang berkaitan dengan sumber daya alam dan potensi lain di daerahnya.menggunakan model pembelajaran kooperatif tipe jigsawdalam kegiatan belajar mengajar. Pada Penelitian Tindakan Kelas (PTK) diperoleh hasil-hasil penelitian yang akan dibahas sebagai berikut :

1. Pembahasan dari setiap siklus Peningkatan aktivitas peserta didik.Hasil pengamatan pada siklus I dengan rata-rata yang dikategorikan baik. Dari gabungan nilai rata-rata hasil pengamat I dan II pada siklus I diperoleh nilai dengan rata-rata 3,38 dikategorikan baik. Pembelajaran yang disampaikann oleh guru direspon dengan baik.peserta didik sangat antusias dalam bertanya dan menjawab pertanyaan dari guru. Sedangkan untuk siklus II dengan rata-rata yang dikategorikan sangat baik. Dari gabungan nilai rata-rata hasil pengamat I dan II diperoleh nilai rata-rata 3,63 dikategorikan baik. Sehingga dengan menggunakan model pembelajaran kooperatif tipe jigsaw aktivitas peserta didik mengalami peningkatan menjadi lebih baik.

2. Pembahasan Hasil Analisis Data Setelah melakukan dan menyalesaikan pembelajaran IPS dengan menggunakan model pembelajaran kooperatif tipe jigsaw maka hasil ketuntasan klasikal dari nilai pretes sebelum diberikannya tindakan kelas jika dilihat dari ketuntasan klasikal memang kurang baik yaitu, 33\% nilai ketuntasan klasikal setelah menggunakan model pembelajaran kooperatif tipe jigsaw pada siklus I meningkat menjadi $58 \%$ dan nilai ketuntasan klasikal pada siklus II lebih meningkat lagi yakni $100 \%$. Jika dicermati lebih mendalam pada hitungan diatas nampak bahwa semua peserta didik dari 12 orang atau sebanyak $100 \%$ peserta didik pada siklus II memperoleh nilai lebih dari 65. Hal ini jika dilihat dari segi ketuntasan belajar maka peserta didik dinyatakan tuntas. Disisi lain dapat dilihat bahwa dengan adanya pembelajaran IPS menggunakan model pembelajaran kooperatif tipe jigsaw ternyata telah memacu peserta didik untuk lebih giat belajar dan aktif dalam pembelajaran sehingga 
Tunas Jurnas Pendidikan Guru Sekolah Dasar, Juni 2018 Volume 3 Nomor 2, (31-37) ISSN 2477-6076

dampaknya pada hasil belajar lebih meningkat

\section{KESIMPULAN}

1. Aktivitas belajar peserta didik dalam pembelajaran IPS dengan menggunakan model pembelajaran kooperatif tipejigsaw pada peserta didik kelas IV SDN-2 Kasongan Baru tahun pelajaran 2016/2017, menjadi lebih baik hal ini terbukti setelah dilaksanakan dalam proses kegiatan belajar mengajar pada siklus I dengan keaktifan peserta didik diperoleh nilai 3,38 dengan kategori baik. Pada siklus II data keaktifan peserta didik meningkat menjadi 3,6 yang dikategorikan baik.

2. Ada peningkatan hasil belajar IPS setelah menggunakan model pembelajaran kooperatif tipe jigsaw pada peserta didik kelas IV SDN-2 Kasongan Baru pada tahun pelajaran 2016/2017. " kegiatan ekonmi dalam memanfaatkan sumber daya alam". Pada siklus I perolehan nilai rata-rata peserta didik yaitu 69,2 dengan ketuntasan klasikal 58\%. Dan pada siklus II diperoleh nilai rata-rata peserta didik sebesar 94,2 dengan ketuntasan secara klasikal sebesar $100 \%$ dikategorikan tuntas.

\section{DAFTAR PUSTAKA}

Kunandar. 2008. Langkah Mudah Penelitian Tindakan Kelas
Sebagai Pengembangan

Prefesi Guru. Jakarta:

Raja Grafindo Persada.

Arikunto, Suharsimi, dkk.

Penelitian Tindakan

Kelas. 2014. Jakarta: PT.

Bumi Aksara 
Tunas Jurnas Pendidikan Guru Sekolah Dasar, Juni 2018 Volume 3 Nomor 2, (31-37) ISSN 2477-6076 